\title{
Growth Performance of Mirror Carp (Cyprinus carpio var. specularis, Lacepède, 1803) Fry Fed with Varying Protein Content Feeds
}

\author{
S.M. Rahman*, M.A.A. Shahin, M.A.H. Chisty, M.M. Rahman, A.M.H.B. Tareque \\ and M.M. Hasan \\ Fisheries and Marine Resource Technology Discipline, Khulna University, Khulna - 9208, Bangladesh. \\ *E-mail:mustafizfmrt@yahoo.com
}

\begin{abstract}
An experiment was conducted in aquaria for seven weeks to examine the effect of varying dietary protein level on growth, FCR (food conversion ratio) and survival of mirror carp fry. Similar weight $(2.29 \pm 0.08 \mathrm{~g})$ and length $(4.21 \pm 0.05 \mathrm{~cm})$ of mirror carp fry were stocked in the aquaria $(1$ fry/L) and fed laboratory prepared feeds containing $25 \%\left(\mathrm{~T}_{1}\right), 30 \%\left(\mathrm{~T}_{2}\right), 35 \%\left(\mathrm{~T}_{3}\right), 40 \%\left(\mathrm{~T}_{4}\right)$, and $45 \%\left(\mathrm{~T}_{5}\right)$ protein. In terms of growth and FCR, diet containing $30 \%$ protein performed significantly $(\mathrm{p}<0.01)$ better than those of other tested diets. Survival rate, on the other hand, dropped significantly $(\mathrm{p}<0.01)$ when the stocks were fed diets containing over $30 \%$ protein. These findings suggest that about $30 \%$ protein in diet appears to be sufficient for obtaining optimum growth of mirror carp fry.
\end{abstract}

Key words: Mirror carp, protein, growth, FCR and survival.

\section{Introduction}

Protein is the major dietary nutrient affecting performance of fish (Lovell, 1989). It provides the essential and nonessential amino acids which are necessary for muscle formation and enzymatic function and in part provides energy for maintenance (Yang et al., 2002). It is also important to minimize the amount of protein used for energy, because protein is usually the most expensive major constituents in a diet. Insufficient as well as excess level of protein in feed is not desirable; the former results in poor growth, while the later would be wasted by diverting for energy. On the other hand, the most crucial stages of larval development of fish are the first feeding stage of larvae when hatchlings start to feeding from yolk materials until absorb or external sources. Since it is a transitional period and the protein levels vary according to the stages, the fishes require time to adapt to its new feeding habit. Mass mortality of the fry often occurs at this stage due to failure of adoption. Hence, dietary protein level in fish feed needs to be optimized accurately for particular fish and its stages.

Several experiments have been conducted to determine the optimal level of protein for various fish species (Ogino and Saito, 1970; Dabrowski, 1977; Hepher, 1990; De Silva and Anderson, 1995; Pramanik el al., 1997). Optimum dietary protein requirement of mirror carp fry, however, remains poorly understood. Mirror carp is a suitable species for culture in 
Bangladesh because it grows in any water bodies especially in shallow water and exhibits remarkable growth performance within short time and minimum effort. Although fry of mirror carp are successfully reared with live feed, there are several unavoidable problems associated with natural live food organisms. Availability of live food organism depends on environmental factors, as a result they have not been found round the year and their collection from natural habitat is laborious as well as time consuming. Artificial/supplementary diets could be alternative food for large scale operation. In this context, the present study was undertaken in the aquaria to evaluate the growth and survivability of mirror carp fry fed with different protein content feeds $(25 \%, 30 \%, 35 \%, 40 \%$ and $45 \%)$ prepared from different local feed ingredients (rice bran, wheat flour, rice polish, mustard oil cake, and fish meal). This study also addresses the issue of FCR (food conversion ratio) under various experimental diets.

\section{Materials and methods}

\section{Fry collection and maintenance}

One thousand hatchery-reared mirror carp fry of uniform size (weight, $2.29 \pm 0.08 \mathrm{~g}$ and length, $4.21 \pm 0.05 \mathrm{~cm}$ ) were collected from local hatchery and held in three tanks for seven days to acclimatize them to laboratory-rearing conditions. During the period of acclimatization, the fish were fed laboratory prepared diet that contains $25 \%$ protein.

\section{Diet preparation}

Feed ingredients like fish meal, rice bran, wheat bran, wheat flour, and mustered oil cake were collected from the local market and determined the protein level (in percent) following AOAC (1990). Protein ratio of each ingredient and the amount $(\mathrm{g})$ of each ingredient for each diet are presented in Table 1. Five types of diets were prepared by adjusting these ingredients in such a way to obtain $25 \%, 30 \%, 35 \%, 40 \%$ and $45 \%$ protein (according to Pearson, 1976) and named as $T_{1}, T_{2}, T_{3}, T_{4}$ and $T_{5}$, respectively. Pegabind, a synthetic binder was used as a binder of fish feed while fish meal and mustard oil cake were used as basal ingredients. All ingredients were mixed with required water (in semi-moist form) and passed through an electrical extruder pellet machine to obtain pellet. Pellets were then sun dried for three days and kept in refrigerator until use. Protein level of each prepared diet was also determined.

\section{Experimental System}

The experiment was conducted for seven weeks (49 days) in the laboratory of Fisheries and Marine Resource Technology Discipline, Khulna University. Collected fry were reared with continuous aeration in aquaria $\left(50 \times 30 \times 30 \mathrm{~cm}^{3}\right)$ containing 15 liter of water at a stocking density of 1 fry/L. The fry were fed twice daily (morning and evening) at the rate of $5 \%$ of their total biomass. Each treatment was conducted with the replication of three. About onethird water from each aquarium was replaced with clean water every day before feeding. Uneaten feed and feces in each aquarium were removed by siphoning and the dead fry (if any) were removed and recorded in the morning and in the evening prior to feeding. Adhered dirt inside the aquarium walls was cleaned twice a week.

Weight $(\mathrm{g})$ and length $(\mathrm{cm})$ of about 10 fry were measured every week from each 
S.M. Rahman, M.A.A. Shahin, M.A.H. Chisty, M.M. Rahman, A.M.H.B. Tareque and M.M. Hasan / Our Nature (2012) 10: 17-23

tank using electric balance (B303-S, Metler Toledo) and simple measuring scale, respectively. Weight gain, length gain, specific growth rate (SGR), feed conversion ratio (FCR) and survival rate were calculated in accordance with the following formula:

$\begin{array}{lc}\text { Weight gain }(\mathrm{g}) & =\text { Mean final weight } \\ - \text { mean initial weight. } & \\ \text { Length gain }(\mathrm{cm}) & =\text { Mean final length } \\ - \text { mean initial length. } & \\ \text { Specific growth rate } & =\{(\text { Ln final weight } \\ & - \text { Ln initial } \\ & \text { weight }) / \mathrm{cu} \\ & \text { lture } \\ & \text { period }\} \\ & 100\end{array}$

Feed conversion ratio $=$ Dry weight of feed/ Wet weight gain

Survival rate $\quad=($ Number of live fish/Total number stocked fish) $\times 100$

\section{Water Quality Parameters}

Water quality parameters such as temperature, dissolved oxygen (DO), $\mathrm{pH}$, and alkalinity were recorded daily throughout the experimental period but the results are presented in weekly basis. Temperature and DO of each tank were recorded by a mercury thermometer and DO meter (Lutron DO-5510), respectively. The $\mathrm{pH}$ was determined with the help of $\mathrm{pH}$ meter (Hanna ISO 9001). The alkalinity of the water sample was determined with neutralization titration method and total alkalinity was assessed by the following equation:

Alkalinity $\left(\mathrm{mg} \mathrm{CaCO}_{3} / \mathrm{l}\right)=\mathrm{A} \quad \mathrm{x} \quad \mathrm{N}$ $50000 / \mathrm{ml}$ of sample

$\left(\mathrm{H}_{2} \mathrm{SO}_{4}\right)$ acid used $(0.1 \mathrm{~N})$

$$
\mathrm{N} \text { = normality of standard }
$$

\section{Statistical analysis}

Data was analyzed with Microsoft excel to evaluate the growth performance with the changes of time. ANOVA test was done at $95 \%$ significant level.

\section{Results and discussion}

Growth performance was indicated by absolute growth, percentage increase in live weight, SGR and survival rate when subject to analysis of variance revealed significant influence of protein level (Table 2). The average initial and final weight of mirror carp fry for treatments $T_{1}, T_{2}, T_{3}, T_{4}$, and $T_{5}$ were between 2.29 to $4.02 \mathrm{~g}, 2.29$ to $5.26 \mathrm{~g}$, 2.29 to $4.56 \mathrm{~g}, 2.29$ to $3.89 \mathrm{~g}$, and 2.29 to $3.26 \mathrm{~g}$, respectively. The treatment, $\mathrm{T}_{2}$ differed significantly $(\mathrm{P}<0.01)$ from other treatments $\left(\mathrm{T}_{1}, \mathrm{~T}_{3}, \mathrm{~T}_{4}\right.$, and $\left.\mathrm{T}_{5}\right)$ while no significance $\quad(\mathrm{P}>0.01)$ differences were observed within the treatments of $\mathrm{T}_{1}, \mathrm{~T}_{3}, \mathrm{~T}_{4}$, and $\mathrm{T}_{5}$. The highest weight gain (g) of fish was observed for diet containing 30\% protein followed by $35 \%, 25 \%, 40 \%$, and $45 \%$.

Present findings indicated that fish fed with diet having $30 \%$ protein $\left(\mathrm{T}_{2}\right)$ reflected the best growth in terms of live weight gain $(129.7 \%)$ with the specific growth rate being $1.71 \%$. Similarly to this study, Singh et al., 2006; Rahman et al., 2006 and Tareque et al., 2009 reported 30\% incorporated protein in diet resulted better results with respect of growth and SGR for Labeo rohita, Cyprinus carpio Var. Nudus and Puntius gonionotus, respectively. This experiment further revealed that protein content over $30 \%$ did not increase the growth even in some case drastically 
S.M. Rahman, M.A.A. Shahin, M.A.H. Chisty, M.M. Rahman, A.M.H.B. Tareque and M.M. Hasan / Our Nature (2012) 10: 17-23

reduced the growth. For instant, diet containing $45 \%\left(\mathrm{~T}_{5}\right)$ had showed lower growth performance compared to fish fed only $25 \%\left(\mathrm{~T}_{1}\right)$ protein.

In contrast, Dabrowski (1977) found the highest gain in body protein in grass carp at the optimum dietary protein level (45.56\%) while Pramanik et al. (1997) reported that maximum growth of Cirrhina mrigala was observed when the fish fed at $35 \%$ protein content feed. They further noticed that gradual decrease of fish growth appear when the protein content of the feed decrease or increase from the optimum level. The tendency of such growth pattern was also observed in this study (Fig. 1). Excess protein results in high level of ammonia production, which might affect voluntary feed intake and growth of fish (Kaushik and Medale, 1994). Working with other common carp species, Ogino and Satio (1970) noted that fish feed containing $38 \%$ protein is suitable for growth. Level of protein requirements of carp fry reported by Dabrowski (1977) and Pramanik et al. (1997) are not consistence with the present findings. Species specific difference might be a major cause for the variation of growth.

SGR was found as $1.14,1.71,1.28$, 0.94 , and $0.72 \%$ for $\mathrm{T}_{1}, \mathrm{~T}_{2}, \mathrm{~T}_{3}, \mathrm{~T}_{4}$, and $\mathrm{T}_{5}$, respectively (Table 2$)$. The highest SGR (\% per day) value was found at $30 \%$ and the lowest was observed at $45 \%$ protein level feeds. SGR (\% per day) values obtained in this study were varied between 0.72 to 1.71 where lower values $(0.08-0.53)$ were obtained by Rahman et al. (2006) for the fry of Cyprinus carpio Var. Nudus. The higher weight gain of fish observed in the present study than that of Rahman et al. (2006) works might be due to the better utilization of prepared diet by the fish.
Fig. 2 represents the relationship between absolute growth and feed conversion ratio (FCR). Absolute growth was found as 1.73, 2.96, 2.27, 1.7 and 0.98 for $\mathrm{T}_{1}, \mathrm{~T}_{2}, \mathrm{~T}_{3}, \mathrm{~T}_{4}$, and $\mathrm{T}_{5}$, respectively. On the other hand, FCR was found as 8.06, 4.31, 6.8, 7.76 and 12.7 for $\mathrm{T}_{1}, \mathrm{~T}_{2}, \mathrm{~T}_{3}, \mathrm{~T}_{4}$, and $\mathrm{T}_{5}$, respectively. The highest absolute growth was observed for treatment $T_{2}$ where minimum feed were utilized by fish while opposite results were obtained for $T_{5}$. Treatment, $\quad \mathrm{T}_{2}$ differed significantly $(\mathrm{P}<0.01)$ with other treatments $\left(\mathrm{T}_{1}, \mathrm{~T}_{3}, \mathrm{~T}_{4}\right.$, and $\mathrm{T}_{5}$ ) and no significance differences $(\mathrm{P}>0.01)$ were observed among the treatments of $\mathrm{T}_{1}, \mathrm{~T}_{3}, \mathrm{~T}_{4}$, and $\mathrm{T}_{5}$

The food consumption and wet weight production play an important role in the increase or decrease of FCR. FCR is a measure of diet efficiency. The more suitable the diet the less feed is required to produce a unit weight gain i.e. lower FCR. The FCR values of the present study are comparable to the findings of Rahman et al., 2006; Tareque et al., 2009 for other common carp species but not satisfactory for Indian major carps (Singh et al. 2006; Pramanik et al., 1997) and grass carp (Dabrowski, 1977), need further study.

After 49 days of culture, fish in $\mathrm{T}_{2}$ (99\%) showed the lowest survival rate followed by $\mathrm{T}_{1} \quad(93 \%), \quad \mathrm{T}_{3} \quad(90 \%), \quad \mathrm{T}_{4}$ $(83.34 \%)$, and $\mathrm{T}_{5}(68 \%)$. No significant differences $(\mathrm{P}>0.01)$ in the survival rate were observed between the treatments $T_{1}$ and $\mathrm{T}_{2}$ but differed significantly $(\mathrm{P}<0.01)$ between $T_{3}, T_{4}$ and $T_{5}$ (Table 2 ). The highest survival rate were obtained in the diet containing 30\% protein level might be due to the comparatively favorable culture condition prevailed in the aquaria. The survival rate of fish fed with different feeds 
S.M. Rahman, M.A.A. Shahin, M.A.H. Chisty, M.M. Rahman, A.M.H.B. Tareque and M.M. Hasan / Our Nature (2012) 10: 17-23

ranged from 70 to $93 \%$, which is line with the findings of Rahman et al. (2006) and Tareque et. al. (2009). Lowering the survival rate in treatment $\mathrm{T}_{5}$ could be due to the fact of access ammonia production induced by maximum protein incorporation in diet, as discussed previously. It is known that there is a direct relationship between ammonia and $\mathrm{pH}$. In this experiment, we did not quantify the ammonia production in

Table 1. Protein content (\%) of each ingredient and the formulation of different levels of protein rich feed from the various feed ingredients (Dry weight basis).

\begin{tabular}{|c|c|c|c|c|c|c|}
\hline \multirow[t]{2}{*}{ Ingredients } & \multirow[t]{2}{*}{ Protein (\%) } & \multicolumn{5}{|c|}{ Amount of ingredients (g) } \\
\hline & & $\mathbf{T}_{1(25 \%)}$ & $\mathbf{T}_{2(30 \%)}$ & $\mathbf{T}_{3(35 \%)}$ & $\mathbf{T}_{4(40 \%)}$ & $\mathbf{T}_{5(45 \%)}$ \\
\hline Fish meal & 45.96 & 22.95 & 30.84 & 40.74 & 46.63 & 56.12 \\
\hline Mustard oil cake & 10.10 & 7.65 & 7.65 & 7.65 & 7.65 & 18.71 \\
\hline Wheat flour & 4.69 & 41.64 & 34.53 & 24.41 & 18.29 & 15.10 \\
\hline Rice bran & 3.91 & 13.88 & 13.88 & 13.88 & 13.88 & 5.03 \\
\hline Rice polish & 3.50 & 13.88 & 13.88 & 13.88 & 13.88 & 5.03 \\
\hline Total & & 100 & 100 & 100 & 100 & 100 \\
\hline
\end{tabular}

Table 2. Growth performance and survival rate of mirror carp fry fed on different formulated diets. Dissimilar superscripts in the same row exhibited significant difference ( $\mathrm{P}<0.01$, ANOVA test). Each value represents mean $\pm \mathrm{SD}$

\begin{tabular}{llllll}
\hline \multirow{2}{*}{ Parameters } & \multicolumn{5}{c}{ Treatments } \\
\cline { 2 - 6 } & $\mathbf{T}_{\mathbf{1}(\mathbf{2 5} \%)}$ & $\mathbf{T}_{\mathbf{2}(\mathbf{3 0} \%)}$ & $\mathbf{T}_{\mathbf{3}(\mathbf{3 5} \%)}$ & $\mathbf{T}_{\mathbf{4}(\mathbf{4 0})}$ & $\mathbf{T}_{\mathbf{5}(\mathbf{4 5})}$ \\
\hline Initial weight $(\mathrm{g})$ & $2.29^{\mathrm{a}} \pm 0.1$ & $2.29^{\mathrm{a}} \pm 0.08$ & $2.29^{\mathrm{a}} \pm 0.08$ & $2.29^{\mathrm{a}} \pm 0.08$ & $2.29^{\mathrm{a}} \pm 0.08$ \\
\hline Final weight $(\mathrm{g})$ & $4.02^{\mathrm{a}} \pm 0.1$ & $5.26^{\mathrm{b}} \pm 0.35$ & $4.56^{\mathrm{a}} \pm 0.20$ & $3.89^{\mathrm{a}} \pm 0.18$ & $3.26^{\mathrm{a}} \pm 0.05$ \\
\hline Absolute growth $(\mathrm{g})$ & $1.73^{\mathrm{a}} \pm 0.9$ & $2.96^{\mathrm{b}} \pm 0.15$ & $2.27^{\mathrm{a}} \pm 0.36$ & $1.7^{\mathrm{a}} \pm 0.18$ & $0.98^{\mathrm{a}} \pm 0.05$ \\
\hline Relative growth (\%) & 75.55 & 129.26 & 99.13 & 74.24 & 42.79 \\
\hline SGR $\left(\%\right.$ day $\left.^{-1}\right)$ & $1.14^{\mathrm{ab}} \pm 0.2$ & $1.71^{\mathrm{b}} \pm 0.16$ & $1.28^{\mathrm{ab}} \pm 0.14$ & $0.94^{\mathrm{ab}} \pm 0.09$ & $0.72^{\mathrm{ab}} \pm 0.02$ \\
\hline Survival Rate (\%) & $93.33^{\mathrm{c}} \pm 1.2$ & $93.33^{\mathrm{c}} \pm 1.7$ & $90.00^{\mathrm{bc}} \pm 4.7$ & $83.34^{\mathrm{b}} \pm 3.5$ & $70.00^{\mathrm{a}} \pm 4.7$ \\
\hline
\end{tabular}

Table 3. Water quality parameters under different treatments during the study period (mean \pm SD)

\begin{tabular}{llllll}
\hline \multirow{2}{*}{ Parameters } & \multicolumn{5}{c}{ Treatments } \\
\cline { 2 - 6 } & $\mathbf{T}_{\mathbf{1 ( 2 5} \%)}$ & $\mathbf{T}_{\mathbf{2}(\mathbf{3 0} \%)}$ & $\mathbf{T}_{\mathbf{3}(\mathbf{3 5} \%)}$ & $\mathbf{T}_{\mathbf{4}}(\mathbf{4 0 \% )}$ & $\mathbf{T}_{\mathbf{5}(\mathbf{4 5} \%)}$ \\
Temperature $\left({ }^{\circ} \mathrm{C}\right)$ & $29.5 \pm 0.03$ & $29.7 \pm 0.01$ & $29.5 \pm 0.09$ & $29.6 \pm 0.03$ & $29.6 \pm 0.07$ \\
$\mathrm{pH}$ & $8.8 \pm 0.04$ & $8.6 \pm 0.01$ & $8.6 \pm 0.1$ & $8.5 \pm 0.08$ & $8.7 \pm 0.2$ \\
DO (mg/l) & $4.7 \pm 0.02$ & $6.8 \pm 0.06$ & $6.2 \pm 0.3$ & $6.5 \pm 0.04$ & $5.2 \pm 0.1$ \\
Alkalinity $\left(\mathrm{mg} \mathrm{CaCO}_{3} / \mathrm{l}\right)$ & $166.7 \pm 0.4$ & $186.4 \pm 0.6$ & $191.7 \pm 0.8$ & $200.1 \pm 0.4$ & $178.1 \pm 0.7$ \\
\hline
\end{tabular}


S.M. Rahman, M.A.A. Shahin, M.A.H. Chisty, M.M. Rahman, A.M.H.B. Tareque and M.M. Hasan / Our Nature (2012) 10: 17-23

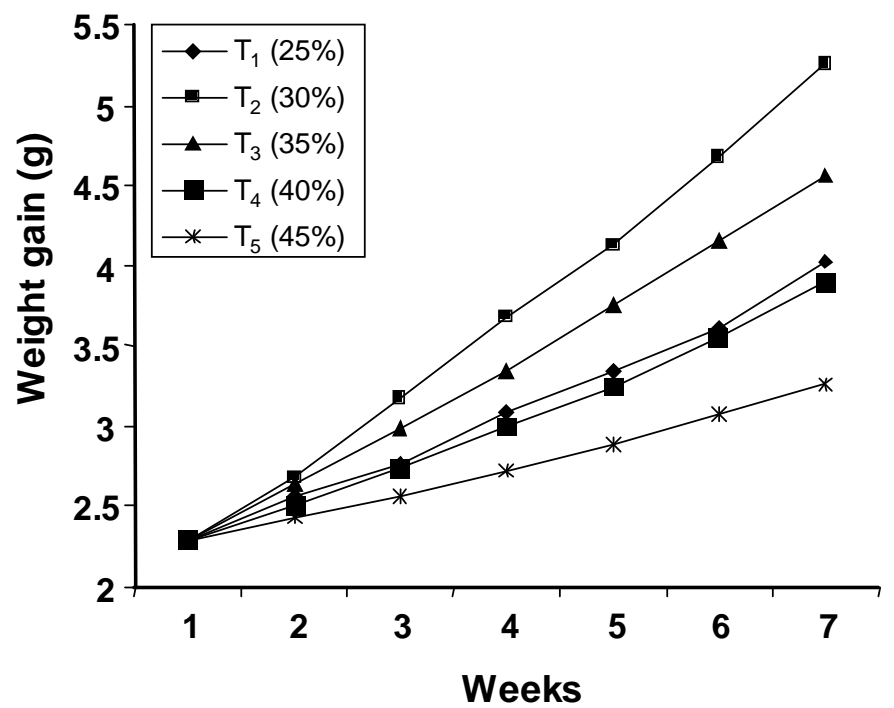

Figure 1. Effect of different levels of protein on weight gain of mirror carp fry throughout the experiment.

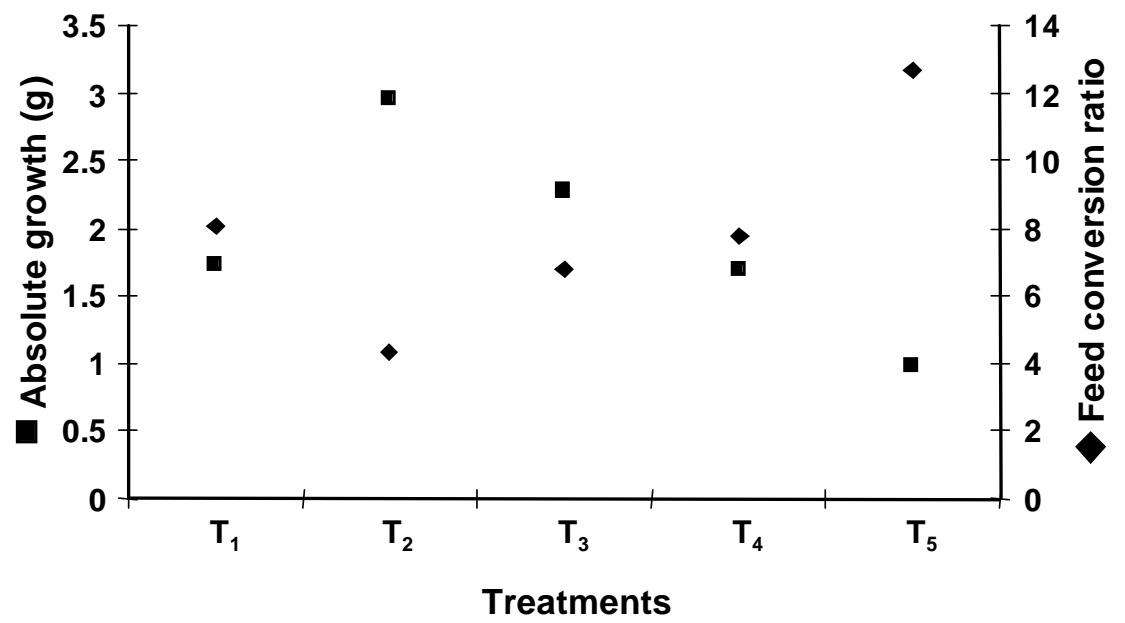

Figure 2. Relation between absolute growth and feed conversion ration under different treatments.

culture media but we measured the $\mathrm{pH}$ value in each treatment. During the study period, we did not find any abnormal changes of $\mathrm{pH}$ (Table 3) and all values were suitable recommend by several authors (Renukaradhya and Varghese, 1986;
Hossain et al., 1998). Comprehensive but isolating experiment is needed to explore such paradox in future.

In conclusion, experimental diet containing 30\% protein resulted in good weight gain, specific growth rate, feed 
S.M. Rahman, M.A.A. Shahin, M.A.H. Chisty, M.M. Rahman, A.M.H.B. Tareque and M.M. Hasan / Our Nature (2012) 10: 17-23

conversion ratio and survival rate for the fry of Mirror carp.

\section{References}

AOAC 1980. Official Methods of Analysis. Association of Official Agricultural Chemist. $10^{\text {th }}$ ed. Washington, D.C. p 957.

Dabrowski, K. 1977. Protein requirement of grass carp fry (Ctenopharyngodon idella). Aquaculture 12: 63-73.

De Silva, S.S and T. Anderson 1995. Fish nutrition in aquaculture. Chapman and Hall aquaculture series 1. pp 147-179.

Hepher, B 1990. Fish nutrition of pond fishes. Cambridge university press. pp 147-149.

Hossain, M.A., A.K.M.A. Shah, S.M. Rahmatullah and M.S.A. Sarker 1998. Effect of supplementary feeding methods on growth of Thai sharpunti, Puntius goniontus (Bleeker) in earthen miniponds. Bangladesh J. Fish. 21(1):99-103.

Kaushik, S.J. and F. Medale 1994. Energy requirement, utilization and dietary supply to salmonids. Aquaculture 121: 81-97.

Lovell, R.T 1989. Nutrition and Feeding of Fish. Van Nostrand Reinhold, New York, p 260.

Ogino, C. and K. Saito 1970. Protein in fish-1. The utilization of dietary protein in young carp. Bull. Jap. Soc. Sci. Fish. 36:250-254.
Pearson, D 1976. The Chemical Analysis of Foods. Churchill Livingstone, Edinburgh. p 574.

Pramanik, M.W.A., M.A. Mazid, M.A. Hossain and J.N. Akter 1997. Nutritional requirements of major carp - III. Optimum level of dietary protein for mrigal (Cirrina mrigala). Bangladesh J. Fish. 20 (1-2):121-125.

Rahman, M.M., S.K. Paul, S.M. Rahman, A.M.H.B. Tareque and M.A.A. Shahin 2006. Growth and survival of leather carp (Cyprinus Carpio Var. Nudus) fry fed with different protein content feeds. South Asian J. Agri. 1(2):17-23.

Renukaradhya, K.M. and T.G.Varghese 1986. Protein requirement of carps, Catla catla (Hamilton) and Labeo rohita (Hamilton). Proc. of the Indian Acad. of Sci. 95:103 - 107 .

Singh, P.K., S.R. Gaur and M.S. Chari 2006. Effect of varying protein level on the growth of Indian Major carp Rohu, Labeo rohita (Hamilton). Intenat. J. Zoo. Res. 2(2): $186-191$.

Tareque, A.M.H.B., M.M. Alam, M.M. Rahman, M.M. Rahman and S. M. Rahman 2009. Effect of some formulated feeds on the growth and survival of Thai Sharpunti (Puntius gonionotus) fry. Bang. J. Mar. Sci. and Fish. 1(1): 21-31.

Yang, S.D., C.H. Liou and E.G. Liu 2002. Effect of dietary protein level on growth performance, carcass composition and ammonia excretion in juvenile silver perch (Bidyanus bidyanus). Aquaculture 213:363-372. 